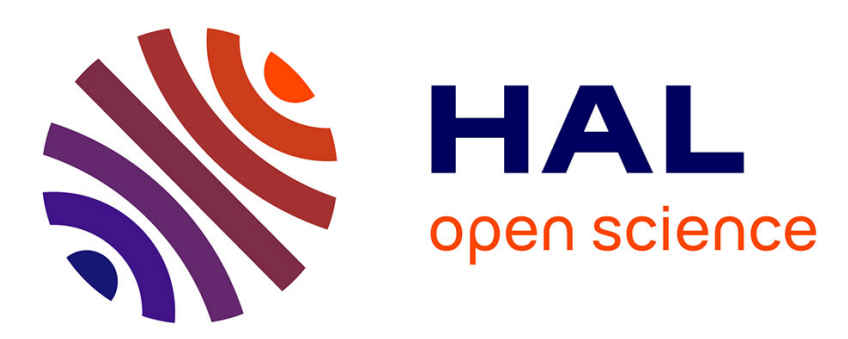

\title{
Determinants of Adaptation Costs in Procurement: An Empirical Estimation on Italian Public Works Contracts
} Calogero Guccio, Giacomo Pignataro, Ilde Rizzo

\section{To cite this version:}

Calogero Guccio, Giacomo Pignataro, Ilde Rizzo. Determinants of Adaptation Costs in Procurement: An Empirical Estimation on Italian Public Works Contracts. Applied Economics, 2011, pp.1. 10.1080/00036846.2011.556589 . hal-00687731

\section{HAL Id: hal-00687731 \\ https://hal.science/hal-00687731}

Submitted on 14 Apr 2012

HAL is a multi-disciplinary open access archive for the deposit and dissemination of scientific research documents, whether they are published or not. The documents may come from teaching and research institutions in France or abroad, or from public or private research centers.
L'archive ouverte pluridisciplinaire $\mathbf{H A L}$, est destinée au dépôt et à la diffusion de documents scientifiques de niveau recherche, publiés ou non, émanant des établissements d'enseignement et de recherche français ou étrangers, des laboratoires publics ou privés. 


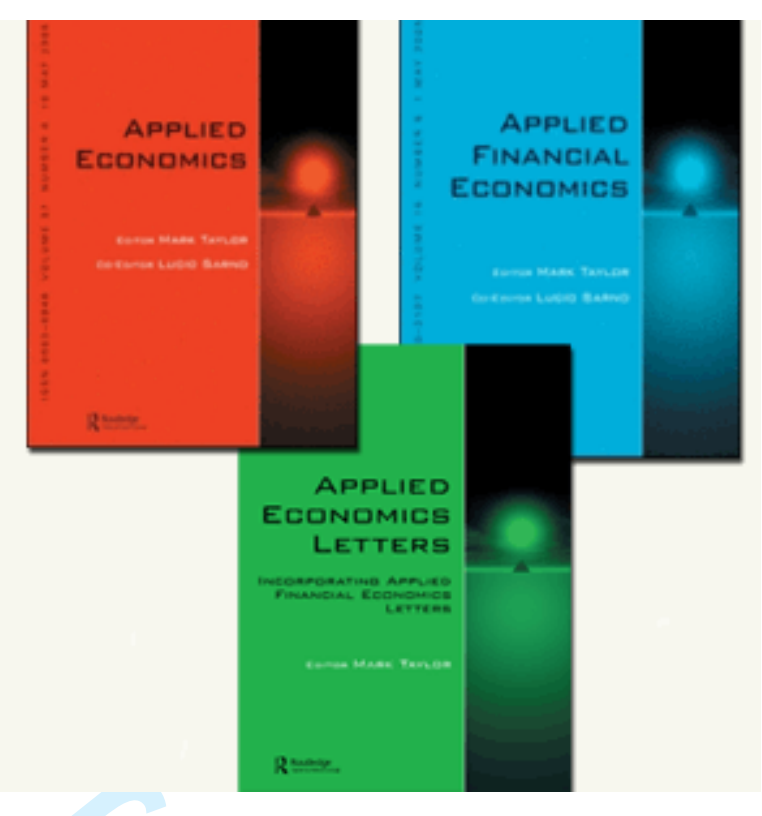

\section{Determinants of Adaptation Costs in Procurement: An Empirical Estimation on Italian Public Works Contracts}

\begin{tabular}{|c|c|}
\hline Journal: & Applied Economics \\
\hline Manuscript ID: & APE-08-0458.R1 \\
\hline Journal Selection: & Applied Economics \\
\hline $\begin{array}{r}\text { Date Submitted by the } \\
\text { Author: }\end{array}$ & 01-Jun-2010 \\
\hline Complete List of Authors: & $\begin{array}{l}\text { Guccio, Calogero; University of Catania, Faculty of Law } \\
\text { Pignataro, Giacomo; University of Catania, Faculty of Economics } \\
\text { Rizzo, Ilde; University of Catania, Faculty of Economics }\end{array}$ \\
\hline JEL Code: & $\begin{array}{l}\text { H57 - Procurement < H5 - National Government Expenditures and } \\
\text { Related Policies < H - Public Economics, D23 - Organizational } \\
\text { Behavior|Transaction Costs|Property Rights }<\text { D2 }- \text { Production and } \\
\text { Organizations < D - Microeconomics, L14 - Transactional } \\
\text { Relationships|Contracts and Reputation|Networks }<\text { L1 - Market } \\
\text { Structure, Firm Strategy, and Market Performance }<\text { L - Industrial } \\
\text { Organization, C34 - Truncated and Censored Models < C3 - } \\
\text { Econometric Methods: Multiple/Simultaneous Equation Models }<\text { C - } \\
\text { Mathematical and Quantitative Methods }\end{array}$ \\
\hline Keywords: & procurement, public work, cost overruns \\
\hline
\end{tabular}




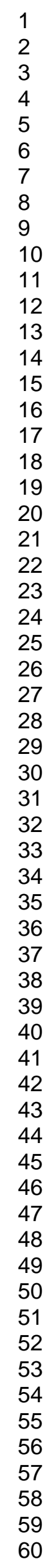

\section{$\$$ Manuscript Central}




\title{
Determinants of adaptation costs in procurement: an empirical estimation on Italian public works contracts
}

\author{
C. Guccio ${ }^{a^{*}}$, G. Pignataro a and I. Rizzo ${ }^{a}$ \\ ${ }^{\mathrm{a}}$ Department of Economics and Quantitative Methods, University of Catania, Corso Italia, 55 C.P. \\ 95121, Catania, Italy
}

\begin{abstract}
It is widely agreed that rules governing public procurement should be designed to achieve value for money. However, in the public works sector, “... the good being procured is usually complex and hard to be exactly specified ex ante, ... [and] alterations to the original project might be needed after the contract is awarded. This may result in considerable discrepancies between the lowest winning bid and the actual costs that are incurred by the buyer" (Bajari et al., 2006). There is now a wide body of literature focusing on cost escalation during the execution of contracts and their estimates reveal that it can be often quite large. The paper is aimed at offering an empirical test of the determinants of adaptation costs in the public works procurement. Using a detailed data set on Italian public works contracts, we run an empirical analysis, grounded on the main conclusions reached in the literature, to test for the main drivers of adaptation costs.
\end{abstract}

\footnotetext{
*Corrisponding author. E-mail: guccio@ unict.it
} 


\section{Introduction}

Procurement objectives can be stated saying that governments should aim at obtaining "value for money", including the quality dimension in the concept of value. The possibility of fulfilling this objective depends on: the selection of the private contractor, the specification of the contract and the enforcement of the contract. The focus of the economic literature has been, for a long time, on the nature of the procedures for selecting contractors and on the specification of the contract. The issues examined are those related to asymmetric information, both in the form of adverse selection (i.e. the problem of choosing the best private contractor) and of moral hazard (i.e. the problem of preventing opportunistic behaviour in the implementation of the contract). More recently, attention has been paid to the phenomenon of cost escalation occurring during the execution of public works contracts. In this sector, in fact, a relevant feature of procurement is that “... the good being procured is usually complex and hard to be exactly specified ex ante, ... [and] alterations to the original project might be needed after the contract is awarded. This may result in considerable discrepancies between the lowest winning bid and the actual costs that are incurred by the buyer" (Bajari et al., 2006).

Indeed, the phenomenon of the increase in planned costs of public projects is a highly debated political as well as economic issue and this paper aims at investigating its determinants on the grounds of the main conclusions reached in the literature.

This paper develops as follows. In section 2, a short economic analysis of the rules on public works in Italy is provided and it is highlighted that the final costs of the works 
very often exceed the expected costs. Section 3 offers a survey of the main results of the literature on the analysis of adaptation costs in public procurement and a specification of the variables used in the paper to represent the main drivers of adaptation costs, as emerging from the several studies in the field.

In section 4 we run an empirical analysis of the main determinants of adaptation costs, using a unique panel data set of public works in Italy; we find support for the main conclusions reached in the literature and we offer some comments on the policy implications of the results. Few concluding remarks are presented in section 5 .

\section{Italian Public Works Market: Rules and Performance}

\section{Italian procurement rules}

The Italian procurement system, during the last fifteen years has been subject to continuous changes.

A reform of public works procurement was initially introduced by the law 11/2/94, n. 109, the so-called legge Merloni, "to improve the efficiency, the effectiveness, the transparency and the quality of public works" (art.1). Since then many changes of this law have been introduced; recently, new rules have been devised and a law was passed (Codice dei contratti pubblici di lavori, servizi, forniture) which transposes 
the EU Directive n. 2004/18/CE on the coordination of procedures for the award of public works, public supply and public service contracts into the Italian legislation ${ }^{1}$.

No attempt is made here of analysing the Italian legislation and only a few key general features will be recalled. Italian procurement rules are quite strict in specifying how decisions should be taken (for instance, "award to the lowest bidder"), or what process has to be followed in making a decision (for instance, "do not accept late proposals", "evaluate proposals only based on the evaluation criteria in the solicitation"). The law tries to reduce bureaucratic discretion as much as possible $^{2}$. On these grounds, preference is given to competition ${ }^{3}$ : procurements $^{-}$ should be widely advertised and strictly evaluated on the basis of the criteria announced in advance. Sealed bids are used to prevent collusion among the participants and to ensure transparency. In other words, competition is promoted as much as possible, as a tool to select the most convenient bidder ${ }^{4}$. As far as the specification of the contract is concerned, cost plus contracts are not allowed, so as to prevent opportunistic behaviour of private contractors, and the renegotiation of the contract is severely constrained ${ }^{5}$.

\footnotetext{
${ }^{1}$ Italy being a member State of the European Union, its legislation on procurement needs to be designed according with the principles set up in the EU Directive.

${ }^{2}$ As Kelman (2002) points out, these features strongly characterized the USA procurement before the legislative reforms passed in 1994, 1995 and 1998.

${ }_{3}$ Open procedures are the rule and negotiated procedures can be adopted only in well defined circumstances.

${ }^{4}$ This is in line with the more traditional results of the economic literature on auctions. For an overview of this literature see Klemperer (1999).

5 The law specifies under what specific circumstances renegotiation is allowed, as well as the maximum amount, which is permitted, and the authorization procedure required. When a bigger renegotiation is needed, the contract is revoked and a new tender is issued. The project designer is liable for the mistakes in the project, which cause major revisions and, therefore, the revocation of the contract.
} 
Indeed, the «philosophy» underlying the above mentioned procurement rules does not always seem in line with the economic reality of procurement (though the recent reform of the Italian legislation would seem to introduce some slight changes in this direction, whose effects cannot be assessed yet). However, emphasis is mainly placed on competition as a tool to ensure the selection of the best contractor, on the assumption that it will also provide the minimization of costs for the contracting authority $^{6}$. Indeed, procurement rules aimed at ensuring competition might not be effective in producing the expected final outcome. As Kelman (1990) stresses, the use of sealed bids, i.e. purchasing with anonymous sellers, is in contrast with any purchasing practice in the industrial sector. In fact, customers and suppliers cannot enjoy the value deriving from long term, continuing relationships such as those characterising private sector industrial purchasing ${ }^{7}$, though the undesirable lock-in effect should be not underestimated. Potentially relevant incentives for good performance, such as a promise to award future contracts, are ruled out. These shortcomings might be especially relevant when centralized procurement procedures are used.

A peculiar feature of the Italian procurement is given by the existence of an independent Authority (Autorità di Vigilanza sui contratti pubblici di lavori, servizi e forniture) established in 1999, for the legal supervision of public works and

\footnotetext{
${ }^{6}$ Expected total costs do not necessarily decrease when the number of bidders increases: the administrative costs as well as the costs for the preparation of the bid should not be undervalued.

${ }^{7}$ The advantages of such a kind of relationship have been stressed by Williamson (1985).
} 
engineering services and nowadays operating in all the areas of procurement ${ }^{8}$. The role of the Authority is to diffuse and to supervise the proper implementation of effective regulation by the public authorities and the contractors, as well as to collect data on the procurement sector.

\section{The performance of the Italian public works market}

As far as public works are concerned, it is useful to point out that such a complex array of norms is designed to regulate a market of relevant size: in 2006, in Italy, the demand of public works totally amounted to about 30,721 millions of euros ${ }^{9}$. The Italian public works market is fragmented both in terms of the tender size and the number of purchasing authorities ${ }^{10}$.

The above mentioned regulation does not seem effective, however, in ensuring the functioning of the market, i.e. the capability of fulfilling on time the public need underlying the demand for public works. In fact, table 1 shows that, in the period $2000-2005,101,589$ works above 150,000 euros have been awarded and that only 27,529, mainly of small size, were completed.

\section{$<<$ TABLE 1 around here $>>$}

\footnotetext{
${ }^{8}$ Rizzo (2008) points out that the creation of an independent Authority to supervise and regulate the procurement market is not widespread in other EU countries and offers a tentative political economy explanation.

${ }^{9}$ Autorità di vigilanza sui contratti pubblici di lavori, servizi e forniture (2007). The demand is not evenly distributed across the different geographical areas and the different sectors.

${ }^{10}$ In 2006 there were 12,231 public works below 150,000 euros ( $38.1 \%$ of the total) and, at the other extreme, 150 works above 15 millions of euros. $83 \%$ of works was below 1 million of euros (Autorità di vigilanza sui contratti pubblici di lavori, servizi e forniture, 2007).
} 
The performance of the Italian public works market is, indeed, a very 'hot' and debated issue: it is widely recognised that infrastructures play a strategic role to foster economic growth ${ }^{11}$ and the improvement of the procurement system is advocated to overcome the present under-provision of infrastructures. Nowadays, a major concern is that not only just a small share of the awarded contracts is completed, but also that the final costs and the duration of the works which are completed very often exceed the expected costs and duration.

In this paper we focus attention upon adaptation costs that is the cost of adapting post-award changes. We are aware that there is no unambiguous way to refer to such a phenomenon ${ }^{12}$ but, apart from terminological disputes, in this paper we refer to adaptation costs as the difference between actual, or final costs and the contract costs as a ratio of the contract costs, where the contract costs are those representing the value of the winning bid. More formally, they are expressed as: $A C_{h}=\frac{F C_{h}-B_{h}}{B_{h}}$, where $F C_{h}$ is the final cost and $B_{h}$ is the value of the winning bid, for a public work $h$.

\footnotetext{
${ }^{11}$ The effects of infrastructures on economic growth are extensively investigated in the literature (see, Milbourne et al., 2003; Wilhelmsson and Wigren, 2009).

${ }^{12}$ Flyvbjerg et al. (2002) provide a similar definition for cost overruns, which is the other term usually encountered in this literature: "actual costs minus estimated costs in percent of estimated costs", where estimated costs are those forecasted at the time of the decision to realize the project. The authors are well aware, however, of the fact that estimated costs can be computed at different times: project planning, decision to build, tendering, contracting, etc. It also must be noted that the term adaptation costs is sometimes used with a substantially different meaning. Bajari et al (2006) define adaptation costs as "any costs that are incurred above and beyond the direct production costs of the project", whereas they consider the direct production costs as the other source of the cost increases following a modification of the initial plan, that is the direct costs of the additional work.
} 
The Authority's estimates ${ }^{13}$ show that almost two thirds of the public works completed by 2005 experienced adaptation costs and for about a quarter of all works, adaptation costs were higher than $10 \%$ of the original $\operatorname{cost}^{14}$. Therefore, data about Italian public works carried out between 2000 and 2005 seem to suggest that adaptation costs are empirically relevant.

The performance of Italian public works market, measured by the extent of the phenomenon of adaptation costs, therefore, shows interesting economic implications, which need to be investigated empirically. The phenomenon of adaptation costs is not new in the literature and its determinants have been extensively investigated: in the following section, the main contributions offered in this field will be analysed to provide a theoretical framework for the analysis of Section IV.

\section{The determinants of adaptation costs}

There is now quite a wide body of literature on the analysis of adaptation costs in public procurement, attempting to explain the different sources of the increase in planned costs of public projects and to provide supporting and consistent empirical evidence. In this section, we will briefly survey the main results of this literature, to elicit the factors that are widely recognized as main drivers of adaptation costs, and to

\footnotetext{
${ }^{13}$ Autorità di vigilanza sui contratti pubblici di lavori, servizi e forniture (2006).

${ }^{14}$ At the same time, in Italian public works delays are very striking: about two thirds of public works completed by 2005 involved delays higher than $20 \%$ of the completion time agreed upon in the contract. The determinants of such a phenomenon have been investigated by Guccio et al. (2009b).
} 
relate them to the variables we will use to test their empirical relevance in the analysis for the Italian public works, which will be developed in the next section.

\section{A brief survey of the literature}

Complexity, uncertainty and the inescapability of adaptation. First of all, most works emphasize that whereas public procurement is not concerned with provision of standard goods and services, and it regards complex goods, like public works, there will be an unavoidable degree of uncertainty related to events that may occur during the execution of the contract, which may cause a difference between what is planned and what is actually realized, or needs to be realized. One potential explanation of adaptation costs, then, lies in the inadequate way of dealing with uncertainties in the planning stage, in terms, for instance, of poor initial design, which requires substantial changes in the execution stage, or of inaccuracy of costs forecasts ${ }^{15}$. This is what has been termed as technical explanation by Flyvbjerg (2005), for the case of large infrastructure projects: "Technical explanations account for cost overruns and benefit shortfalls in terms of imperfect forecasting techniques, inadequate data, honest mistakes, inherent problems in predicting the future, lack of experience on the part of forecasters, etc." Studies of forecasting errors (Flyvbjerg and Skamris, 1997; Flyvbjerg et al., 2002, 2003a) show that construction costs are generally

\footnotetext{
${ }^{15}$ Ganuza (2007) provides a rational explanation for what could be regarded as underinvestment in project design. A higher investment on a more accurate initial design lowers the probability of renegotiation and of awarding the project to the most efficient firm, but it increases its rents, when competition is not perfect.
} 
underestimated, and costs escalation, in general, is more severe for mega projects and for long time of completion ${ }^{16}$. However, over time, "technical error may be reduced or eliminated by developing better forecasting models, better data, and more experienced forecasters" (Flyvbjerg, 2005). Even if negligence in dealing with uncertainty should disappear over time, there may still be contingencies that are really impossible to be predicted, above all for very complex projects. This observation, coupled with the pervasiveness of contractual incompleteness, leads to the need of renegotiation of original contracts and, possibly, to adaptation costs. The issue of contractual incompleteness has been extensively investigated in the contract theory (Hart 1995) and the explanations provided for its existence seem all relevant in the case of public works.

Optimism bias and political incentives to underestimation of costs. A second explanation provided for adptation costs is still related to an "imperfect" project design, which is not caused by "objective" reasons but by a subjective will to underestimate costs, when designing the project. Studies using the notion of "optimism bias" are in this line of thought. This notion has mainly psychological foundations and it represents a more general explanation of business behavior and even of individual behavior. According to Lovallo and Kahneman (2003) ${ }^{17}$, "when forecasting the outcomes of risky projects, executives all too easily fall victim to what

\footnotetext{
${ }^{16}$ Odeck (2004), however, shows that, in the case of the Norwegian road sector, cost overruns appear to be more severe for smaller projects as compared to larger ones.

${ }^{17}$ See also Kahneman and Tversky (1979) and Flyvbjerg (2005), among the other studies that develop the idea of optimism bias.
} 
psychologists call the planning fallacy. In its grip, managers make decisions based on delusional optimism rather than on rational weighting of gains, losses, and probabilities. They overestimate benefits and underestimate costs... As a result, managers pursue initiatives that are unlikely to come in on budget or on time". The psychological nature of this optimism can be tracked down to several cognitive biases suffered by individuals ${ }^{18}$. Newby-Clark et al. (2000) provide experimental evidence of individuals' optimistic views about time completion of some tasks, even when they have information about other potential, and more pessimistic scenarios. It is not, however, straightforward to extend the experimental results to the context of public works, to prove the existence of optimism bias and to regard it as a determinant of adaptation costs. Flyvbjerg (2005) noted that: i) the experimental data are drawn from non-expert individuals; ii) if optimism bias has to be considered as an explanation for adaptation costs in public works, it would be able to explain individual cases of innacuracy, while the phenomenon is widespread and persistent over time. Flyvbjerg et al. (2003b) show, for instance, for a sample of transport infrastructure projects covering 20 different countries over 70 years, that nine out of ten projects suffer from cost escalation. Moreover, it is possible to add that, if connected to a psychological basis, optimism bias is difficult to be represented in an empirical test, since the initial underestimation of costs may be representative of different factors. Indeed, optimism bias or, more generally, a "voluntary" underestimation of costs could be considered,

\footnotetext{
${ }^{18}$ Lovallo and Kahneman (2003) refer to the tendency of individuals to exaggerate their own talents, or the degree of control over events, to anchoring, that is a project plan comes out as an adaptation of an original idea, etc.
} 
instead, as connected with political incentives to behave in such a way ${ }^{19}$. An optimistic design of a work may represent an instrument for changing priorities across different projects, for creating a commitment to the realization of a work, facilitating its start up, or for producing short term political benefits, as arising from the possibility of increasing the number of works to be started, even if, in the medium-long term they will be delayed or even not completed, because of financial problems. There are a few studies trying to prove that political behavior is at work, behind the existence of adaptation costs, with the help of anecdotal evidence (Wachs, 1989; Wachs, 1990; Flyvbjerg et al., 2002). It turns out that the behavior of political decisionmakers, in overestimating the net benefits of projects, is interpreted in terms of lying, something that cannot be represented by observed data. Therefore, the authors of these studies need to turn to interviews to people that have played a role in the design and approval of public works, to check whether political pressure has led to overstate benefits and underestimate costs.

Opportunistic behavior. A third relevant driver of adaptation costs, widely discussed in the literature, is related to the potential opportunistic motivation of rinegotiation of contracts for public works, especially on the side of firms: when a contract for a public work has been awarded, the firm can exploit the unavoidable

\footnotetext{
${ }^{19}$ Flyvbjerg (2005) regards political incentives to overestimation of benefits and underestimation of costs as a separate explanation of cost overruns. However, Lovallo and Kahneman (2003) consider also organizational pressure as a source of optimism bias: "Every company has only a limited amount of money and time to devote to new projects. Competition for this time and money is intense, as individuals and unit jockey to present their own proposals as being the most attractive for investment. Because forecasts are critical weapons in these battles, individuals and units have big incentives to accentuate the positive in laying out prospective outcomes". In general, therefore, optimism bias can also have a rational foundation.
} 
contract incompleteness, to gain additional money over and above what has been agreed upon in the contract ${ }^{20}$. In other words, the modification of the initial plans may be driven by the incentive of the firm to exploit its bargaining power in bilateral negotiations with procurers, who may suffer by being "locked" into the contract with the firm. The relevant contributions here are especially those examining some procurement features that may affect the strength of the incentives to behave opportunistically during renegotiation, mainly connected with the nature of the contract and with the contract awarding procedure. These studies re-examine, then, the efficiency properties of mechanisms, like fixed price contracts and auctions, considering how ex-ante incentives may affect ex-post renegotiation and bargaining and, consequently, adaptation costs. As for the first issue, the nature of the contract, several studies have compared fixed price with cost plus contracts. Bajari and Tadelis (2001), in particular, show that procurers may face a trade-off between providing ex ante incentives and avoiding ex post transaction costs due to costly renegotiation: "FP contracts provide the strongest incentives for cost reduction. On the other hand, if the design is left incomplete, then the cost of renegotiating FP contracts is high. When $\mathrm{C}+$ contracts are used the cost-reducing incentives disappear, but the process of adaptation is far smoother because the reimbursement process is simple, well defined, and leaves little room for haggling." The costs arising from fixed-price contract, related to adaptation of projects, tend to be higher as the complexity of projects increases, since the potential for adaptation increases with complexity. Therefore,

\footnotetext{
${ }^{20}$ Within the context of concession contracts, Guasch (2004) has examined the potential incentive of governments in renegotiating contracts.
} 
“cost-plus contracts are preferable to fixed-payment contracts when a project is highly complex and the cost of ex ante contract preparation and specification is large" (Estache et al., 2009). With respect to the issue of the impact of procurement awarding procedures on adaptation costs, the analysis is part of the research that compares auctions with negotiations. A first line of argument holds that negotiations transmit more information to the firm than auctions, and, for this reason, may help preventing the need and scope of renegotiation. Bajari et al. (2009) argue that the only piece of information the bidders receive in auctions is the bid, while in negotiation the parties have usually the opportunity to discuss the details of the project. This is the reason why negotiations should help to attenuate the need for adaptation and, therefore, the impact on adaptation costs when procurement regards complex projects. A second relevant issue raised about the relationship between awarding procedures and adaptation costs is that, with incomplete contracts, the winning bidders in auctions may have an incentive to behave opportunistically, during the execution of the contract, and to push for revising the bid that allowed them to win the award of the work (Guasch, 2004). This may be part of a situation of adverse selection, whereas a bidder that is ready to act opportunistically, at the execution stage, will bid a very low price (what is usually referred to as underbidding), so as to secure the win of the bid and, then, to exploit the opportunity of a renegotiation (Bajari et al., 2009; Chong et al. 2009, Guccio et al., 2009a) ${ }^{21}$.

\footnotetext{
${ }^{21}$ Ware et al. (2007) present this behavior, also known as lowballing, as part of a colluding agreement with procurers, who would guarantee the winner a convenient renegotiation, sharing the gains, which will arise.
} 
Corruption. Finally, adaptation costs are surely influenced by corruption. Guasch (2004) shows that the likelihood of renegotiation increases with the level of corruption of a country, while Auriol (2006) estimates the cost of corruption to be between 4 and 10 percent of procurement spending.

The variables used to represent the determinants of adaptation costs

Complexity. Complexity of projects, then, may be associated to a negligent or "objective" overlooking of contingencies, which requires renegotiation of the original agreement between the procurer and the firm, because of contractual incompleteness. Complexity is, in fact, related to several characteristics of works, which are uneasily expressed by just one dimension. We will try to capture the impact of complexity on adpatation costs, considering different variables. The expected time duration of the work $(\boldsymbol{E D})$, as fixed at the time of signing the contract, is the first of these variables: the longer the time needed to complete a work, the higher the risk of occurrence of contingencies not foreseen in the original contract. Another variable is represented by the estimated total value of the work $(\boldsymbol{E T} \boldsymbol{V})$ by the contracting authority, since it seems reasonable to assume that a "larger" work presents a higher degree of complexity and a higher risk of not considering every contingency at the planning stage. Finally, exploiting the Italian classification of public works and the fact that, for each public work, there is a record of all the categories in which it can be decomposed, a weighted composition index of the work (WCI) is computed, calculated on the different sub-categories involved in the work, weighted for their 
relative amount ${ }^{22}$. We will also make an attempt to measure the impact on adaptation costs of the problems related to the execution of the work, which may also include errors or poor design. One of the variables we will use is the existence of legal disputes (DIS) between the firm and the purchasing authority. It is representative of problems with the execution of the work, which are not solved by an agreement between the parties, and it may be partially connected with the quality of the initial design. A poor design can be contested by the firm, because it cannot be executed or it is too costly to be executed. It can also be executed in a different way, which is considered as more efficient by the firm, but it is however contested by the contracting authority. We are well aware that the existence of legal disputes is connected to several other reasons, first of all defects of execution of the work by the firm, and that its impact on adaptation costs will also measure the legal costs connected with the dispute itself. We will, therefore, be cautious in the interpretation of the results. We will also consider that the Italian law admits the possibility, for the contracting authority, to procure not only the work, but also the final design of the project. We will use a dummy variable to capture whether the contract includes the final design of the project or not (PROJ). The effects of this variable, however, are not unambiguous: on one hand, the lack of an executive project and therefore, the possibility for the firm to intervene on the project could allow for the adoption of technical solutions consistent with its productive capacities and know-how and,

\footnotetext{
${ }^{22}$ Public works are articulated in sub-categories, i.e. the different components of the overall work, which contribute, according with their relative relevance for the specific work, to the estimated total value. It is plausible to assume that the more complex is a public work the higher is the number of sub-categories involved in its implementation.
} 
therefore, could reduce the pressure on the renegotiation and adaptation cost during the implementation. On the other hand, however, the separation of the activities of project and implementation introduces a conflict of interests between the project designer and the firm implementing the work and, therefore, may limit the firm's opportunistic behaviour. Finally, we control for the presence of subcontractors in the execution of the work $(\boldsymbol{S U} \boldsymbol{B})$, since it may negatively affect the implementation of the original design, even when the latter does not present serious limitations.

Political incentives. Since our empirical analysis is based on data on public works carried out by very different authorities, we will try to capture the effect of political incentives to underestimate costs, considering the different governance models of the contracting authorities $^{23}$. To grasp the relation between the governance and the performance of the contract, contracting authorities have been grouped in the following categories: central government (State administrations even with autonomous organization - $\boldsymbol{C} \_\boldsymbol{G O} \boldsymbol{V}$ ), local governments (regions, provinces, municipalities - $\boldsymbol{L} \_\boldsymbol{G} \boldsymbol{O} \boldsymbol{V}$ ), institutions (Public institutions, Health Authorities, which enjoy budget autonomy - INST), public ownership companies (ANAS, FS, Poste s.p.a. $-\boldsymbol{P} \_\boldsymbol{E N T}$ ) and private companies (e.g. concessionaires $\left.-\boldsymbol{P R I V} \boldsymbol{C}_{-} \boldsymbol{O M}\right)^{24}$. Our hypothesis is that central government on one side and private companies, on the

${ }^{23}$ Different models of governance refer to appointment methods, soft or hard budget constraints, etc. It must be noted that a different governance model may also impinge on incentives to monitoring the implementation of the work.

${ }^{24}$ A somewhat similar differentiation of contracting authorities can be found in Bandiera et al. (2009), a work analyzing the behaviour of Italian procurers in the purchase of standardized goods. 
other, are the 'polar' cases as far as incentives are concerned. Moving from the former extreme to the latter we would expect lower adaptation costs ${ }^{25}$.

Opportunistic behaviour. Since the Italian procurement of public works is mainly ruled by the criterion of fixed price, in this work, we cannot test the different impact of the nature of the contract on adaptation costs. We will check, instead, for the relation between the type of awarding procedure and adaptation costs, using a dummy variable, according to whether it is an auction or a negotiation $(\boldsymbol{O P E N})$. We will also check whether underbidding and its intensity affect the extent of renegotiation and its adaptation costs. The variable used to capture underbidding is the ratio of the value of the winning bid to the value of the work $\left(\boldsymbol{R}_{-} \boldsymbol{W B I D} \_\boldsymbol{E T V}\right)$, as estimated by the contracting authority. We are aware of the fact that, behind this variable, other phenomena may be hidden. However, the variables related to the governance of contracting authorities help us in controlling for potential incentives to underestimation of costs (the denominator of our variable). It must also be considered that what we would regard as underbidding could be, instead, the natural outcome of competition in the market for public works. More generally, the value of the winning bid is affected by the nature of the market. We try to control for different market features. To control for the effects of competition on the bid, we will use the number of potential bidders $-\boldsymbol{P}_{-} \boldsymbol{B I D}$ - (i.e. the number of firms qualified for the specific

\footnotetext{
${ }^{25}$ The relations of causality between the difference of cost and the procurement procedure for each contracting authority need to be explored. A lower difference of cost for a category of contracting authority might not be determined necessarily by a more careful behaviour but by a larger use of negotiated procedures (which reduce the risk of contractual revisions).
} 
public work category -e.g. roads, railways, etc.- and for the specific contract value at national level). It is also important to evaluate the position of the winning bidder within the market. We will, therefore, use a variable, measuring the number of contracts awarded to each firm by all the contracting authorities included in the data set in the period under consideration $(\boldsymbol{L E A D})$ : in a market in which tendering is effective in selecting the best bidder, and assuming that quality is homogeneous across firms for the works of the same category and size, the greater this number, the higher the probability that the firm is more efficient than others, so being able to offer lower prices, without increasing adaptation costs. Finally, we will consider a proxy for the potential existence of long-term relationships between the firm and the purchasing authority, represented by the number of contracts awarded to each firm by the same purchasing authority (INT). The expected sign for this variable is negative, since the interaction is likely to prevent opportunistic behaviour and, therefore, the greater the interaction, the lower the likelihood of contractual revisions and adaptation costs.

Corruption. We will use a proxy for corruption proposed by Golden and Picci (2005), based on the difference between a measure of the physical quantities of public infrastructure and the cumulative price government pays for public capital stocks $($ GP_INDEX). 
Control factors. We will consider the ratio between the actual duration of the work and the expected duration $\left(\boldsymbol{E} \boldsymbol{X} \_\boldsymbol{T}\right)$ to control for the relative delay of the different works. We will also control for year of award, through dummies for each year (2000, 2001, 2002, 2003 and 2004) and compare estimates, where public works sectors are pooled to others, where we also control for sectors.

\section{Empirical analysis}

\section{Data and descriptive statistics}

The data used in the following analysis are those collected by Osservatorio per $i$ lavori Pubblici of the Autorità di Vigilanza sui contratti pubblici di lavori, servizi e forniture. The observation unit is given by the single public work and very detailed information are available on the various steps of the procurement procedure - project, selection of the contractor, execution and completion of the work. The sample refers to 9,888 public works, whose costs range from 150,000 euros to 5 million euros, awarded in the period 2000-2004 and completed by $2005^{26}$. Table 2 provides summary statistics for the number of contracts awarded per year, the total amount and the mean value of contracts.

\section{$<<$ TABLE 2 around here $>>$}

\footnotetext{
${ }^{26}$ The sample was also selected on the basis of the completeness of the records included in the data base. To limit the heterogeneity, the public works above 5 million euros were not included in the sample because of the longer time lag required to complete complex works. Moreover, public works with a final cost lower than the contract cost were not taken into account because of the lack of adequate information.
} 
Altogether, the sample is representative of the composition of public works in Italy, both in terms of sectors and of contracting authorities. Tables 3 and 4, respectively show the composition of the sample in terms of the sectors covered and of the type of contracting authorities, grouped in five categories, according to their different governance structure. With respect to the value of the works, the data show a high variability across sectors and contracting authorities. Table 3 indicates that public works in the sample are mainly referable to roads and highways, social and school buildings and protection of environment, which account for about $60 \%$ of the entire sample, in terms of both the number of works and their value. Table 4 reveals that most of the works represented in the sample are carried out by local governments.

\section{$<$ TABLE 3 around here $>>$ \\ $<$ TABLE 4 around here $\gg>$}

\section{Econometric framework}

The aim of this section is to provide a test of the empirical relevance of the different factors discussed in section III, in the explanation of adaptation costs. For this purpose, we employ a panel data of Italian public works for 16 sectors awarded in the period 2000-2004 and completed by 2005. The dependent variable is the adaptation cost $(\boldsymbol{A C})$ for project $\boldsymbol{i}$ in sector $\boldsymbol{j}$, as defined in section II. 
Because of the censoring of these data at zero $^{27}$, ordinary least squares (OLS) regression techniques are not applicable, as least squares estimates are not consistent when the residuals are not normally distributed. A natural approach is to use a Tobit $\operatorname{model}^{28}$, with the following empirical specification:

$$
A C_{i j}=\beta_{0}+\beta E V_{i j}+\varepsilon_{i j}
$$

where $\boldsymbol{E} \boldsymbol{V}$ is a vector of independent variables, already identified and described in section III, and $\varepsilon$ an i.i.d. and normally distributed error term. The notation for identifying each independent variable is explained in Table 5, and their descriptive statistics are shown in Table 6.

\section{$<$ TABLE 5 around here $>>$}

\section{$<$ TABLE 6 around here $>>$}

To better account for the heterogeneity across sectors, the regressions draw on panel Tobit random effect ${ }^{29}$, where the error term takes the form:

$$
\varepsilon_{i j}=v_{i}+\mu_{i j}
$$

${ }^{27}$ The range of the variable in the sample is between 0.0000 and 1.8037 .

${ }^{28}$ To control for sample selection we also considered a Tobit II estimate (Amemiya, 1984) achieving comparable results. Estimation can be obtained by the authors upon request.

${ }^{29}$ A standard Tobit fixed effect model would be inconsistent, since the fixed effects cannot be treated as incidental parameters in non-linear models without biasing the other model coefficients (Wooldridge, 2002). 
where $\boldsymbol{v}$ is an unobservable individual effect including a random term with $\sim \mathrm{N}\left(0, \sigma^{2}\right)$, and $\boldsymbol{\mu}$ is an independent random disturbance term assuming normal distribution $\mathrm{N}\left(0, \sigma^{2}\right)$.

We estimate these models using maximum likelihood methods, assuming robust standard errors ${ }^{30}$.

The results of the regression described in [1] are displayed in Table 7: the first column summarizes the estimation results of Tobit model and the second the estimation results of random-effects Tobit model ${ }^{31}$. According to the likelihood ratio tests, the random-effects Tobit estimates are more reliable than the standard Tobit estimates. Thus the following comments are based on the random-effects Tobit estimates.

\section{$<<$ TABLE 7 around here $>>$}

Altogether, the results of the empirical analysis seem to confirm the relevance of the factors, outlined in section III, for the explanation of adaptation costs in the procurement of public works.

Complexity, as measured by the different variables used in our analysis, is a significant factor in the explanation of adaptation costs. As expected, higher levels of complexity increase adaptation costs, for the plausible reason that they may be associated to greater uncertainty and to a higher likelihood of negligent or

\footnotetext{
${ }^{30}$ For panel Tobit with random effects, we use bootstrap with 50 interactions (Cameron and Trivedi, 2005).

${ }^{31}$ We employ this model because of the bias in standard Tobit estimates if an unobservable sector effect is included.
} 
unavoidable deficiencies in the original design, thus raising the need for renegotiation, in the presence of contractual incompleteness.

The existence of legal disputes is associated to higher adaptation costs. Reminding the cautious comments on the interpretation of this variable, as expressed in section III, this result may be also representative of the fact that some of the adaptation costs are originated by problems with the design of the project. The involvement of the firm in the project design seems to increase the adaptation costs and, therefore, there is no positive effect in the sharing of information and knowledge between the firm and the contracting authority. At least, it is more than compensated by the potential negative impact (in terms of increasing adaptation costs) of the reduction of the conflict of interest between the project designer and the firm. The existence of sub contractors seems to have no significant effect on adaptation costs.

As far as the relevance of political incentives is concerned, our analysis shows that all the models of governance different from central government (with the exception of local governments) have a significant effect on adaptation costs, more precisely they tend to be associated to lower adaptation costs. Strangely enough, the effect is stronger for public enterprises than for private companies. This implies that the nature of this effect needs further investigation.

With respect to the relevance of the opportunistic behaviour of the firm, as connected with some features of the awarding procedure, the results show that higher adaptation costs tend to be associated with auctions as well as underbidding. The results are robust, since both variables used in the analysis (the dummy for open tendering procedures and the ratio between the winning bid and the estimated total value) are 
significant, with the expected sign. The variables controlling for market conditions do not play a significant role. The number of potential bidders and the number of contracts awarded to the winning bidder are not always significant, and when they are so, the size of their effect is negligible. It needs to be stressed that these results do not imply any conclusive judgment on the overall efficiency of the different procurement procedures, since it is not possible to conclude which procedure produces the best outcome for the contracting authority, in terms of minimization of the total cost of construction. However, it makes clear that this outcome may not be completely guaranteed by the competitiveness of the award procedure, but it is also related to the monitoring in the works' implementation stage. Moreover, even if, in principle, there are rules, in the Italian law, that should prevent the opportunistic behaviour of firms, excluding the "too" low or "too" high bids, they seems to be not so much effective in terms of preventing renegotiations ${ }^{32}$.

Furthermore, higher levels of corruption, as measured by the indicator proposed by Golden and Picci (2005) are associated to higher adaptation costs.

Finally, the relative delay in the completion of the work exerts a positive and significant effect on the adaptation costs.

\author{
Robustness checks
}

\footnotetext{
${ }^{32}$ A system for evaluating the bids, based on the notion of standard costs, might be more effective in preventing underbidding because it might reduce the asymmetrical information of the contracting authority.
} 
In order to check for the robustness of our findings, we performed a number of alternative tests that we thought to be relevant.

To test the marginal effect of each variable included in the general specification, a separate regression is carried out for each additional regressor, controlling for year of award, through dummies for each year (2000, 2001, 2002, 2003 and 2004), and for sectors, with panel Tobit random effect ${ }^{33}$.

Our estimates show that the sign and the significance of the coefficients of our variables are not affected by changes in the specification of the model ${ }^{34}$.

Similar results are also obtained when the model is estimated on two sub-samples: one with roads and highways only, which represent almost a third of all our observations, and the other one with the remaining works. With respect to the latter sub-sample, according to the likelihood ratio tests, the random-effects Tobit estimates are more reliable than the standard Tobit estimates ${ }^{35}$. The results we get, when we estimate the model in this sub-sample, made of 6,667 observations for 15 sectors, are substantially identical to the ones for the entire sample. The only exceptions are the coefficient for the variable $\boldsymbol{L}_{-} \boldsymbol{G O} \boldsymbol{V}$, which is still negative but significant, the one for the variable $\boldsymbol{O P E N}$, which is not significant, and, finally, the estimate for the Golden and Picci (2005) index, which is not significant too. This latter result is not surprising, since the index is computed on the infrastructure endowment, at the provincial level. The estimates relative to the road and highways sub-sample are also

\footnotetext{
33 Table A. 2 in the appendix

${ }^{34}$ The only exception is the coefficient of the variable $\boldsymbol{I N T}$, which has a negative and significant effect, differently from the general model. The reason is probably the very modest value of the coefficient.

35 Table A.3 in the appendix.
} 
consistent with the results for the entire sample, even if there are differences in the significance of the coefficients of some variables ${ }^{36}$.

These further tests allow for some other comments. First of all, the factors that may affect adaptation costs can be differentiated, in terms of their impact, across the different sectors. At the sector level, moreover, a particular relevance is attributable to the type of contracting authorities and to the structure of the market which might have different degrees of specialization. The main implication is that should the analysis on adaptation costs be carried out at the sector level, it must take into account these specific factors.

Secondly, our analysis shows that there are some factors, whose impact is pervasive across the different sectors. This is particularly true for the variable measuring the impact of underbidding and for the variable representing the relative delay. This latter effect is not surprising since in the Italian public works market delays in the completion of the public works are relevant and widespread across all the works ${ }^{37}$.

\section{Concluding remarks}

The focus of this paper is on the determinants of adaptation costs in the Italian public works market. The main findings of the literature have been discussed and the relevant factors behind adaptation costs, as emerging in such a literature, have been investigated and tested using an extensive data base of Italian public works.

\footnotetext{
${ }^{36}$ Table A. 4 in the appendix.

${ }^{37}$ See footnote 14 in section II:
} 
Our results suggest that the main drivers of adaptation costs, as recognized in the literature, seem to be relevant also to explain this phenomenon in the Italian public works market.

Complexity is a significant factor in the explanation of adaptation costs. Unlike other studies in the field, however, in our analysis the size of the work, as a measure of complexity, is not a significant factor while the complexity effect is better captured by the expected duration and by the weighted composition index of the work.

As far as political incentives are concerned, our analysis shows that all the models of governance different from central government (with the exception of local governments) tend to be associated to lower adaptation costs.

The opportunistic behaviour of the firm is confirmed as very relevant determinant of adaptation costs, both in terms of the type of procurement procedure adopted and of underbidding. The results are robust and hold also when the analysis is carried out taking into account the sector effects.

Summing up, our analysis far from being conclusive on the determinants of adaptation costs in the Italian public works market offers, however, some tentative policy implications. The fact that the opportunistic behaviour of the firm turns out as a very relevant driver would suggest to enhance the role of reputation in the awarding of the contract. This may counterbalance the "compensation" role that renegotiation can assume, as a way to recover the "losses" from underbidding in competitive procedures. In this case, however, great attention should be paid to the design of proper incentive schemes for the contracting authority. 


\section{ACKNOWLEDGEMENTS}

The authors wish to thank the Autorità di Vigilanza sui contratti pubblici di lavori, servizi forniture for supplying the data used in the analysis. The authors would like to thank three anonymous referees for their helpful comments and suggestions. The usual disclaimer applies. Even if the paper is the result of the joint work of the authors, section IV is attributable to Calogero Guccio.

\section{$\underline{\text { References }}$}

Amemiya, T. (1984) Tobit models: a survey, Journal of Econometrics, 24, 3-61.

Auriol, E. (2006) Corruption in procurement and public purchase, International Journal of Industrial Organization, 24, 867-885.

Autorità di vigilanza sui contratti pubblici di lavori, servizi e forniture, (2006), Relazione al Parlamento per l'anno 2005, Roma.

Autorità di vigilanza sui contratti pubblici di lavori, servizi e forniture, (2007) Relazione al Parlamento per l'anno 2006, Roma.

Bajari, P., Houghton, S. and Tadelis, S. (2006) Bidding for incomplete contracts: an empirical analysis, NBER Working Papers 12051.

Bajari, P., McMillan, R. and Tadelis, S. (2009) Auctions vs. negotiations in procurement: an empirical analysis, Journal of Law, Economics and Organization, 25, 372-399.

Bajari, P. and Tadelis, S. (2001) Incentives versus transaction costs: a theory of procurement contracts, Rand Jorunal of Economics, 32, 387-407.

Bandiera, O., Pratt, A. and Valletti, T. (2009) Active and passive waste in government spending: evidence from a policy experiment, American Economic Review, 99, 1278-1308.

Cameron, A.C. and Trivedi, P.K. (2005) Microeconometrics: methods and applications, New York, Cambridge University Press.

Chong, E., Staropoli, C. and Yvrande-Billon, A. (2009) Auctions versus negotiations in public procurement: looking for new empirical evidence, Mimeo, downloaded from http://economix.u-paris10.fr/pdf/colloques/2009_Florence/Anne-CarineEshien.pdf.

Estache, A., Iimi, A. and Ruzzier, C. (2009) Procurement in infrastructure. What does theory tell us ?, World Bank Policy Research Working Paper 4994

Flyvberg, B. (2005) Policy and planning for large infrastructure projects: problems, causes, cures, World Bank Policy Research Working Paper 3781.

Flyvberg, B., Bruzelius, N. and Rothengatter, W. (2003a) Megaprojects and Risk. An Anatomy of Ambition., Cambridge: Cambridge University Press.

Flyvbjerg, B., Skamris Holm M. and Buhl, S. L. (2003b) How common and how large are cost overruns in transport infrastructure projects ?, Transport Reviews, 23, 71-88. 
Flyvbjerg, B., Skamris Holm, M. and Soren L. Buhl. (2002) Underestimating Costs in Public Works Projects: Error or Lie? Journal of the American Planning Association, 68, 279-95.

Flyvbjerg, B. and Skamris, M. (1997) Inaccuracy of Traffic Forecasts and Cost Estimates on Large Transport Projects, Transport Policy, 4, 141-6.

Ganuza, J.J. (2007) Competition and cost overruns in procurement, Journal of Industrial Economics, 55, 633-660.

Golden, M. A. and Picci L. (2005) Proposal for a New Measure of Corruption Illustrated with Italian Data, Economics and Politics, 17, 37-75.

Guasch, J. L. (2004) Granting and renegotiating infrastructure concessions. Doing it right, Washington D. C., The World Bank.

Guccio, C., Pignataro, G. and Rizzo, I. (2009a) Procedure di selezione dei fornitori e incentivi alla rinegoziazione in contratti incompleti: un' applicazione al settore dei lavori pubblici, Rivista Italiana degli Economisti, XIV, 69-102.

Guccio, C., Pignataro, G. and Rizzo, I. (2009b) The performance of local government in the execution of public works, MPRA Paper No. 16094.

Hart, O. (1995) Firms, Contracts and Financial Structure, Clarendon Lecture in Economics, Oxford, Oxford University Press.

Kahneman, D. and Tversky, A. (1979) Prospect theory: an analysis of decision under risk, Econometrica, 47, 263-291.

Kelman, S. (1990) Procurement and public management. The fear of discretion and the quality of government performance, Washington, American Enterprise Institute Press.

Kelman, S. (2002) Remaking federal procurement, Visions of Governance in the $21^{\text {st }}$ Century Program, Working Paper 3, The John. F. Kennedy School of Government.

Klemperer, P. (1999) Auction theory: a guide to the literature, Journal of Economic Surveys, 13, 227-286.

Lovallo D. and Kahneman, D. (2003) Delusions of success. How optimism undermines executives' decisions, Harvard Business Review, 81, 56-63.

Milbourne, R., Otto, G. and Voss, G. (2003) Public investment and economic growth, Applied Economics, 35, 527-40.

Newby-Clark, I. R., Ross, M., Buehler, R., Koehler, D. J. and Griffin, D. (2000) People focus on optimistics scenarios and disregard pessimistic scenarios while predicting task completion times, Journal of Experimental Psychology: Applied, 6, 171-182.

Odeck, J. (2004) Cost Overruns in Road construction. What Are their Sizes and Determinants?, Transport Policy, 11, 43-53.

Rizzo, I. (2008) The creation of independent authorities in Italy: an inside political economy perspective on the public works Authority, Padovano, F. and Ricciuti, R. (eds.), Institutional reforms in Italy: an economic perspective, New York, Springer- Verlag, 179-195.

Wachs, M. (1989) When planners lie with numbers, Journal of the American Planning Association, 55, 476-479. 
Wachs, M. (1990) Ethics and advocacy in forecasting for public policy, Business and Professional Ethics Journal, 9, 141-157.

Ware, G., Moss, S., Campos, E. and Noone, G. (2007) Corruption in public procurement: a perennial challenge, in Campos, E. and Pradhan, S. (eds.) The many faces of corruption: tracking vulnerabilities at the sector level, 295-334, Washington D. C., The World Bank.

Wilhelmsson, M. and Wigren, R. (2009) The robustness of the causal and economic relationship between construction flows and economic growth: evidence from Western Europe, Applied Economics, doi:10.1080/00036840802600020.

Williamson, O. (1985) The Economic Institutions of Capitalism, New York, The Free Press.

Wooldridge, J. (2002) Econometric Analysis of Cross Section and Panel Data, MIT Press, Cambridge, MA. 
Table 2 - Distribution and summary statistics of contracts by year of award - public works above 150,000 euros (value at current prices)

\begin{tabular}{||l|r|r|r|r|r|r||}
\hline Year & Number of obs. & \multicolumn{1}{c|}{$\begin{array}{c}\text { Total } \\
\text { amount } \\
\text { (million euros) }\end{array}$} & \multicolumn{1}{c|}{$\begin{array}{c}\text { Mean } \\
\text { (euros) }\end{array}$} & \multicolumn{1}{c|}{$\begin{array}{c}\text { St. Dev. } \\
\text { (euros) }\end{array}$} & $\begin{array}{c}\text { Maximum } \\
\text { amount } \\
\text { (euros) }\end{array}$ & $\begin{array}{c}\text { Minimum } \\
\text { amount } \\
\text { (euros) }\end{array}$ \\
\hline 2000 & 2,344 & 1,083 & 462,170 & 508,013 & $4,482,703$ & 150,024 \\
\hline 2001 & 3,117 & 1,246 & 399,754 & 417,029 & $4,815,961$ & 150,047 \\
\hline 2002 & 2,511 & 979 & 389,710 & 384,392 & $4,965,733$ & 150,000 \\
\hline 2003 & 1,485 & 524 & 353,077 & 314,363 & $4,340,000$ & 150,000 \\
\hline 2004 & 431 & 138 & 319,792 & 264,867 & $3,212,078$ & 150,000 \\
\hline Total & $\mathbf{9 , 8 8 8}$ & $\mathbf{3 , 9 7 0}$ & $\mathbf{4 0 1 , 5 0 4}$ & $\mathbf{4 1 5 , 9 0 2}$ & $\mathbf{4 , 9 6 5 , 7 3 3}$ & $\mathbf{1 5 0 , 0 0 0}$ \\
\hline
\end{tabular}

Source: our elaboration on data provided by Autorità di vigilanza sui contratti pubblici di lavori, servizi e forniture

Table 1 - Public works awarded and completed between 2000 and 2005 - public works over 150,000 euros (value at current prices)

\begin{tabular}{|c|c|c|c|c|c|c|c|c|}
\hline \multirow{2}{*}{ Years } & \multicolumn{3}{|c|}{ Public works awarded } & \multicolumn{5}{|c|}{ Public works completed } \\
\hline & Number & $\begin{array}{c}\text { Total amount } \\
\text { (million euros) }\end{array}$ & $\begin{array}{l}\text { Average amount } \\
\text { (euros) }\end{array}$ & Number & $\begin{array}{c}\% \text { of public } \\
\text { works awarded }\end{array}$ & $\begin{array}{c}\text { Total amount } \\
\text { (million euros) }\end{array}$ & $\begin{array}{c}\% \text { of total } \\
\text { amount of } \\
\text { public works } \\
\text { awarded }\end{array}$ & $\begin{array}{l}\text { Average amount } \\
\text { (euros) }\end{array}$ \\
\hline 2000 & 15,829 & 13,874 & 876,470 & 7,183 & 45.38 & 3,911 & 28.19 & 544,535 \\
\hline 2001 & 18,550 & 14,297 & 770,726 & 7,734 & 41.69 & 3,833 & 26.81 & 495,617 \\
\hline 2002 & 19,822 & 16,472 & 831,014 & 6,426 & 32.42 & 2,763 & 16.78 & 430,010 \\
\hline 2003 & 18,709 & 16,983 & 907,723 & 4,355 & 23.28 & 1,644 & 9.68 & 377,527 \\
\hline 2004 & 16,899 & 18,677 & $1,105,192$ & 1,686 & 9.98 & 546 & 2.92 & 323,952 \\
\hline Total & 101,589 & 94,651 & 931,706 & 27,529 & 27.10 & 12,735 & 13.46 & 462,615 \\
\hline
\end{tabular}

Source: Autorità di vigilanza sui contratti pubblici di lavori, servizi e forniture (2007) 
Table 3- Composition of the sample by sector - public works above 150,000 euros (value at current prices )

\begin{tabular}{|c|c|c|c|c|c|c|}
\hline Sector & $\begin{array}{c}\text { Number of } \\
\text { obs. }\end{array}$ & $\begin{array}{c}\text { Total } \\
\text { Amount } \\
\text { (million } \\
\text { euros) }\end{array}$ & $\begin{array}{c}\text { Mean } \\
\text { (euros) }\end{array}$ & $\begin{array}{l}\text { St. Dev. } \\
\text { (euros) }\end{array}$ & $\begin{array}{c}\text { Maximum } \\
\text { amount } \\
\text { (euros) }\end{array}$ & $\begin{array}{c}\text { Minimum } \\
\text { amount } \\
\text { (euros) }\end{array}$ \\
\hline Roads and highways & 3,221 & 1,189 & 369,163 & 365,879 & $4,760,063$ & 150,000 \\
\hline Railways & 63 & 33 & 527,551 & 459,139 & $2,263,251$ & 153,100 \\
\hline Other transport infrastructures & 153 & 88 & 574,308 & 618,239 & $4,214,288$ & 151,000 \\
\hline Works of protection of the environment, of defence of the soil, water resources. & 1,313 & 535 & 407,720 & 407,657 & $4,482,703$ & 150,001 \\
\hline Urbanization works & 738 & 302 & 408,776 & 446,595 & $4,965,733$ & 150,055 \\
\hline Infrastructures of the energy sector & 57 & 24 & 428,221 & 382,748 & $2,325,757$ & 151,910 \\
\hline Telecommunications and data processing technologies & 36 & 11 & 303,896 & 169,394 & 791,551 & 157,089 \\
\hline Infrastructures for the agriculture and the fishing sector & 73 & 31 & 426,938 & 519,342 & $4,389,133$ & 153,702 \\
\hline Infrastructures for industrial activities, commerce and handicrafts sector & 150 & 83 & 554,142 & 578,835 & $3,293,275$ & 156,204 \\
\hline Social and school building & 1,248 & 514 & 411,800 & 409,399 & $4,597,925$ & 150,000 \\
\hline House building & 275 & 143 & 518,765 & 547,303 & $4,374,389$ & 150,000 \\
\hline Cultural Heritage & 456 & 166 & 364,678 & 302,000 & $2,685,411$ & 150,997 \\
\hline Infrastructures for sport, show and tourism & 453 & 170 & 374,526 & 385,980 & $4,564,473$ & 150,097 \\
\hline Building for health care sector & 355 & 150 & 422,599 & 397,920 & $3,253,678$ & 150,237 \\
\hline Other public building & 1,125 & 446 & 396,001 & 447,230 & $4,777,537$ & 150,024 \\
\hline Other transport infrastructures & 172 & 85 & 495,216 & 597,161 & $4,815,961$ & 150,180 \\
\hline Total & $\mathbf{9 , 8 8 8}$ & 3,970 & 401,504 & 415,902 & $4,965,733$ & 150,000 \\
\hline
\end{tabular}

Source: our elaboration on data provided by Autorità di vigilanza sui contratti pubblici di lavori, servizi e forniture

Table 4 - Composition of the sample by purchasing authorities - public works above 150,000 euros (value at current prices)

\begin{tabular}{|c|c|c|c|c|c|}
\hline Purchasing authorities & Number of obs. & $\begin{array}{c}\text { Mean } \\
\text { Amount } \\
\text { (euros) }\end{array}$ & $\begin{array}{l}\text { St. Dev. } \\
\text { (euros) }\end{array}$ & $\begin{array}{c}\text { Maximum } \\
\text { amount } \\
\text { (euros) }\end{array}$ & $\begin{array}{c}\text { Minimum } \\
\text { amount } \\
\text { (euros) }\end{array}$ \\
\hline Central government & 545 & 364,155 & 429,264 & $4,441,529$ & 150,135 \\
\hline Local government & 6,987 & 376,435 & 359,715 & $4,777,537$ & 150,000 \\
\hline Public agencies with special budget autonomy & 1,216 & 509,189 & 569,304 & $4,815,961$ & 150,000 \\
\hline Public ownership companies & 606 & 321,276 & 285,910 & $3,436,940$ & 150,082 \\
\hline Private concessionaires & 534 & 613,454 & 636,289 & $4,965,733$ & 150,024 \\
\hline Total & 545 & 364,155 & 429,264 & $4,441,529$ & 150,135 \\
\hline
\end{tabular}

Source: our elaboration on data provided by Autorità di vigilanza sui contratti pubblici di lavori, servizi e forniture 


\section{Table 5 - Description of variables employed}

\begin{tabular}{|c|c|}
\hline "VARIABLE & DEFINITION \\
\hline \multicolumn{2}{|c|}{ DEPENDENT VARIABLE } \\
\hline$A C$ & Adaptation costs \\
\hline \multicolumn{2}{|c|}{ INDEPENDENT VARIABLES } \\
\hline \multicolumn{2}{|l|}{ Complexity of works } \\
\hline$E D$ & Expected duration \\
\hline$E T V$ & Estimated total value (thousand euros) \\
\hline WCI & Weighted public work composition index \\
\hline DIS & Dummy for legal disputes \\
\hline PROJ & Dummy for contracts including the final project design \\
\hline SUB & Dummy for subcontracting \\
\hline \multicolumn{2}{|l|}{ Political incentives } \\
\hline C_GOV & Central Government \\
\hline$L_{-} G O V$ & Sub-Central Governments \\
\hline INST & Institutions \\
\hline$P \_E N T$ & Public Enterprises \\
\hline PRIV_COM & Private Companies \\
\hline \multicolumn{2}{|l|}{ Opportunistic behavior } \\
\hline OPEN & Dummy for auctions \\
\hline$R_{-}$WBID_ETV & Ratio between the winning bid and the estimated total value \\
\hline$P P_{-} B I D$ & Number of firms qualified for the work category and value \\
\hline LEAD & Number of contracts awarded to a firm in the market \\
\hline INT & Number of contracts awarded to a firm by the same contracting authority \\
\hline \multicolumn{2}{|l|}{ Corruption } \\
\hline G\&P_INDEX & Golden and Picci (2005) infrastructure corruption index at provincial level \\
\hline \multicolumn{2}{|l|}{ Other covariates } \\
\hline$E X_{-} T$ & Ratio between actual duration and estimated duration \\
\hline YEAR_AWARD & Dummies for: $2000,2001,2002,2003,2004$ \\
\hline
\end{tabular}


Table 6 - Summary statistics of variables employed

\begin{tabular}{|c|c|c|c|c|c|}
\hline Variable & Number of obs. & Mean & St. Dev. & Minimum & Maximum \\
\hline \multicolumn{6}{|c|}{ DEPENDENT VARIABLE } \\
\hline$A C$ & 9,888 & 0.09 & 0.14 & 0.00 & 1.80 \\
\hline \multicolumn{6}{|c|}{ INDEPENDENT VARIABLES } \\
\hline \multicolumn{6}{|c|}{ Complexity of works } \\
\hline$E D$ & 9,888 & 212.96 & 139.24 & 3.00 & $1,327.00$ \\
\hline ETV & 9,888 & 401.50 & 415.92 & 150.00 & $4,965.73$ \\
\hline WCI & 9,888 & 1.24 & 0.44 & 0.00 & 3.93 \\
\hline$D I S$ & 9,888 & 0.02 & 0.14 & 0.00 & 1.00 \\
\hline PROJ & 9,888 & 0.20 & 0.40 & 0.00 & 1.00 \\
\hline$S U B$ & 9,888 & 0.78 & 0.42 & 0.00 & 1.00 \\
\hline \multicolumn{6}{|c|}{ Political incentives } \\
\hline $\mathrm{C}_{-} \mathrm{GOV}$ & 9,888 & 0.06 & 0.23 & 0.00 & 1.00 \\
\hline$L_{-} G O V$ & 9,888 & 0.71 & 0.46 & 0.00 & 1.00 \\
\hline INST & 9,888 & 0.12 & 0.33 & 0.00 & 1.00 \\
\hline P_ENT & 9,888 & 0.06 & 0.24 & 0.00 & 1.00 \\
\hline PRIV_COM & 9,888 & 0.05 & 0.23 & 0.00 & 1.00 \\
\hline \multicolumn{6}{|c|}{ Opportunistic behavior } \\
\hline OPEN & 9,888 & 0.81 & 0.39 & 0.00 & 1.00 \\
\hline$R_{-} W B I D \_E T V$ & 9,888 & 0.87 & 0.09 & 0.43 & 1.00 \\
\hline$P \_B I D$ & 9,888 & $2,249.49$ & $1,396.36$ & 1.00 & $5,707.00$ \\
\hline$L E A D$ & 9,888 & 17.88 & 37.91 & 1.00 & 436.00 \\
\hline$I N T$ & 9,888 & 2.42 & 3.38 & 1.00 & 60.00 \\
\hline \multicolumn{6}{|l|}{ Corruption } \\
\hline GP_INDEX & 9,888 & 1.15 & 1.02 & 0.41 & 6.44 \\
\hline \multicolumn{6}{|l|}{ Other covariates } \\
\hline$E X_{-} \_T$ & 9,888 & 1.77 & 1.91 & 0.01 & 128 \\
\hline$D \_2000$ & 9,888 & 0.24 & 0.43 & 0.00 & 1.00 \\
\hline$D \_2001$ & 9,888 & 0.32 & 0.46 & 0.00 & 1.00 \\
\hline D_2002 & 9,888 & 0.25 & 0.44 & 0.00 & 1.00 \\
\hline$D \_2003$ & 9,888 & 0.15 & 0.36 & 0.00 & 1.00 \\
\hline$D \_2004$ & 9,888 & 0.04 & 0.20 & 0.00 & 1.00 \\
\hline
\end{tabular}

Source: our elaboration on data provided by Autorità di vigilanza sui contratti pubblici di lavori, servizi e forniture and Golden and Picci (2005) 


\section{Table 7 - Tobit estimation results for adaptation costs}

\begin{tabular}{|c|c|c|}
\hline \multicolumn{3}{|c|}{$\begin{array}{l}\text { INDEPENDENT VARIABLE: } \boldsymbol{A C} \text { (ADAPTATION COSTS ) } \\
\text { DATA SAMPLE: UNBALANCED PANEL OF 9,888 OBSERVATIONS, RELATIVE } \\
\text { TO } 16 \text { SECTORS }\end{array}$} \\
\hline Explanatory variable & Tobit & Tobit random effects (1) \\
\hline \multirow{2}{*}{ CONSTANT } & $0.451^{* * * *}$ & $0.456^{* * * *}$ \\
\hline & $(0.023)$ & $(0.024)$ \\
\hline \multicolumn{3}{|l|}{ Complexity of works } \\
\hline \multirow[t]{2}{*}{$E D$} & $0.000^{* * * *}$ & $0.000^{* * * *}$ \\
\hline & $(0.000)$ & $(0.000)$ \\
\hline \multirow[t]{2}{*}{$\overline{E T V}$} & 0.000 & 0.000 \\
\hline & $(0.000)$ & $(0.000)$ \\
\hline \multirow[t]{2}{*}{ WCI } & $0.018^{* * * *}$ & $0.016^{* * * *}$ \\
\hline & $(0.004)$ & $(0.004)$ \\
\hline \multirow[t]{2}{*}{$\overline{D I S}$} & $0.031 * *$ & $0.030^{* * *}$ \\
\hline & $(0.012)$ & $(0.012)$ \\
\hline \multirow{2}{*}{$\overline{P R O J}$} & $0.012 * * * *$ & $0.012 * * * *$ \\
\hline & $(0.004)$ & $(0.004)$ \\
\hline \multirow[t]{2}{*}{$S U B$} & 0.003 & 0.003 \\
\hline & $(0.004)$ & $(0.004)$ \\
\hline \multicolumn{3}{|l|}{ Political incentives } \\
\hline \multirow[t]{2}{*}{$L_{-} G O V$} & -0.001 & -0.000 \\
\hline & $(0.009)$ & $(0.010)$ \\
\hline \multirow[t]{2}{*}{ INST } & $-0.024^{* * * *}$ & $-0.019^{* * *}$ \\
\hline & $\begin{array}{ll}(0.007) \\
\end{array}$ & $(0.008)$ \\
\hline \multirow[t]{2}{*}{$P \_E N T$} & $-0.097^{* * * * *}$ & $-0.093^{* * * *}$ \\
\hline & $(0.010)$ & $(0.011)$ \\
\hline \multirow[t]{2}{*}{ PRIV_COM } & $-0.032^{* * * *}$ & $-0.025^{* * *}$ \\
\hline & $(0.010)$ & $(0.011)$ \\
\hline \multicolumn{3}{|l|}{ Opportunistic behaviour } \\
\hline \multirow[t]{2}{*}{ OPEN } & $0.011^{* * *}$ & $0.010^{* * *}$ \\
\hline & $(0.005)$ & $(0.005)$ \\
\hline \multirow[t]{2}{*}{$\overline{R \_W B I D \_E T V}$} & $-0.490^{* * * *}$ & $-0.494 * * *$ \\
\hline & $(0.021)$ & $(0.022)$ \\
\hline \multirow[t]{2}{*}{$P \_B I D$} & $0.000^{*}$ & $0.000^{*}$ \\
\hline & $(0.000)$ & $(0.000)$ \\
\hline \multirow[t]{2}{*}{$\overline{L E A D}$} & $0.000^{* * *}$ & $0.000^{* * *}$ \\
\hline & $(0.000)$ & $(0.000)$ \\
\hline \multirow[t]{2}{*}{ INT } & 0.000 & 0.000 \\
\hline & $(0.001)$ & $(0.001)$ \\
\hline \multicolumn{3}{|l|}{ Corruption } \\
\hline GP_INDEX & $0.004 * *$ & $0.004 *$ \\
\hline & $(0.002)$ & $(0.002)$ \\
\hline Other covariates & & \\
\hline$E X \_T$ & $0.006^{* * * *}$ & $0.006^{* * * *}$ \\
\hline & $(0.001)$ & $(0.001)$ \\
\hline Controlling for year of award & yes & Yes \\
\hline Controlling for sector & pooling & Yes \\
\hline Observations & 9,888 & 9,888 \\
\hline Uncensored & 7,571 & 7,571 \\
\hline Number of sectors & 16 & 16 \\
\hline Rho & -- & 0.01418 \\
\hline Pseudo $R^{2}$ & 0.7611 & -- \\
\hline Log likelihood & 1237.523 & 1292.209 \\
\hline$L R \chi^{2}$ & $\chi^{2}(21)=1232.78^{* * *}$ & -- \\
\hline Wald & -- & $\chi^{2}(21)=1049.51^{* * *}$ \\
\hline (2) LR test ( $p$-value) & -- & 0.0000 \\
\hline
\end{tabular}

Notes: (1) Bootstrap standard errors are reported in parentheses. (2) The LR test is used to compare the Tobit and random-effects Tobit models. Robust standard errors are reported in parentheses

$* * *, * *$ and $*$ denote significance at 1,5 and 10 per cent levels, respectively 


\section{Appendix}

Table A.1 - Correlation between independent variables

\begin{tabular}{|c|c|c|c|c|c|c|c|c|c|c|c|c|c|c|c|c|c|c|}
\hline & OPEN & $\begin{array}{l}\text { R_WBID } \\
\text { _ETV }\end{array}$ & SUB & $\begin{array}{l}\text { PROJ } \\
\end{array}$ & $\overline{\text { EX_T }}$ & $\begin{array}{c}\text { DIS } \\
\end{array}$ & ETV & $\overline{\mathrm{WCI}}$ & $\overline{\mathrm{ED}}$ & $\begin{array}{l}\text { INT } \\
\end{array}$ & P_BID & LEAD & $\overline{\text { C_GOV }}$ & $\overline{\mathrm{L}} \mathrm{C} \mathrm{GOV}$ & INST & P_ENT & PRIV_COM & $\overline{\text { GP_INDEX }}$ \\
\hline OPEN & 1.000 & & & & & & & & & & & & & & & & & \\
\hline R_WBID_ETV & $\begin{array}{ll}-0.278 \\
\end{array}$ & 1.000 & & & & & & & & & & & & & & & & \\
\hline SUB & 0.134 & 0.148 & 1.000 & & & & & & & & & & & & & & & \\
\hline PROJ & -0.028 & -0.015 & -0.030 & 1.000 & 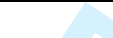 & & & & & & & & & & & & & \\
\hline EX_T & $\begin{array}{ll}-0.014 \\
\end{array}$ & 0.038 & 0.006 & -0.044 & 1.000 & & & & & & & & & & & & & \\
\hline DIS & 0.034 & -0.033 & 0.021 & -0.033 & 0.009 & 1.000 & & & & & & & & & & & & \\
\hline ETV & 0.106 & -0.082 & 0.107 & -0.028 & -0.020 & 0.111 & 1.000 & & & & & & & & & & & \\
\hline WCI & 0.013 & 0.087 & 0.125 & -0.033 & -0.006 & 0.046 & 0.161 & 1.000 & & & & & & & & & & \\
\hline ED & 0.139 & -0.080 & 0.063 & 0.034 & -0.186 & 0.050 & 0.386 & 0.114 & 1.000 & & & & & & & & & \\
\hline INT & -0.134 & 0.032 & -0.012 & 0.158 & -0.048 & -0.024 & 0.046 & -0.026 & -0.028 & 1.000 & & & & & & & & \\
\hline P_BID & 0.157 & 0.074 & 0.069 & -0.028 & -0.009 & -0.012 & -0.062 & 0.096 & 0.066 & -0.050 & 1.000 & & & & & & & \\
\hline LEAD & -0.005 & 0.100 & 0.087 & 0.015 & -0.019 & 0.000 & 0.129 & 0.048 & 0.036 & 0.208 & -0.010 & 1.000 & & & & & & \\
\hline C_GOV & -0.122 & -0.004 & -0.083 & 0.140 & -0.059 & -0.008 & -0.022 & -0.058 & 0.037 & -0.016 & -0.097 & -0.036 & 1.000 & & & & & \\
\hline L_GOV & 0.076 & 0.049 & 0.063 & -0.181 & 0.070 & -0.010 & -0.094 & -0.015 & -0.039 & -0.084 & 0.105 & -0.007 & -0.375 & 1.000 & & & & \\
\hline INST & -0.001 & 0.029 & 0.036 & -0.003 & -0.003 & -0.009 & 0.097 & 0.071 & 0.139 & -0.071 & 0.029 & 0.006 & -0.090 & -0.581 & 1.000 & & & \\
\hline P_ENT & -0.006 & -0.143 & -0.106 & 0.172 & -0.057 & 0.017 & -0.049 & -0.032 & -0.183 & 0.251 & -0.084 & -0.013 & -0.062 & -0.397 & -0.096 & 1.000 & & \\
\hline PRIV_COM & -0.021 & 0.015 & 0.018 & 0.044 & -0.017 & 0.023 & 0.122 & 0.020 & 0.032 & 0.022 & -0.067 & 0.056 & -0.058 & -0.371 & -0.090 & -0.061 & 1.000 & \\
\hline GP_INDEX & 0.062 & -0.377 & -0.232 & 0.037 & -0.040 & 0.010 & 0.035 & -0.028 & 0.090 & -0.038 & 0.000 & -0.095 & 0.114 & -0.096 & 0.031 & 0.028 & 0.004 & 1.000 \\
\hline
\end{tabular}


Table A.2 - Tobit estimation results for adaptation costs

INDEPENDENT VARIABLE: $\boldsymbol{A C}$ (ADAPTATION COSTS )

DATA SAMPLE: UNBALANCED PANEL OF 9,888 OBSERVATIONS RELATIVE TO 16 SECTORS

\begin{tabular}{|c|c|c|c|c|c|c|c|c|c|c|c|c|c|c|}
\hline \multirow{2}{*}{ Explanatory variables } & \multicolumn{14}{|c|}{ Tobit random effects (1) } \\
\hline & (1) & (2) & (3) & (4) & (5) & (6) & (7) & $(8) \#$ & (9) & $(10)$ & $(11)$ & $(12)$ & (13) & (14) \\
\hline \multirow{2}{*}{ CONSTANT } & $0.043^{* * * * *}$ & $0.069^{* * *}$ & $0.066^{* * * * *}$ & $0.081^{* * * *}$ & $0.079^{* * * *}$ & $0.086^{* * * * *}$ & $0.077^{* * * *}$ & $0.100^{* * * *}$ & $0.057^{* * * *}$ & $0.495^{* * * *}$ & $0.084^{* * * *}$ & $0.078^{* * * *}$ & $0.081^{* * * *}$ & $0.080^{* * * *}$ \\
\hline & $(0.010)$ & $(0.010)$ & \begin{tabular}{|l|}
$(0.011)$ \\
\end{tabular} & $(0.010)$ & $(0.010)$ & $(0.011)$ & $(0.010)$ & $(0.013)$ & \begin{tabular}{|l|}
$(0.011)$ \\
\end{tabular} & $(0.020)$ & $(0.010)$ & $(0.011)$ & $(0.010)$ & $(0.011)$ \\
\hline \multicolumn{15}{|l|}{ Complexity of work } \\
\hline \multirow{2}{*}{$E D$} & $0.000^{* * * *}$ & -- & --- & --- & --- & \begin{tabular}{|c|}
-- \\
\end{tabular} & -- & -- & \begin{tabular}{|l|}
-- \\
\end{tabular} & \begin{tabular}{|c|}
-- \\
\end{tabular} & --- & -- & --- & -- \\
\hline & $(0.000)$ & -- & -- & -- & -- & -- & -- & -- & \begin{tabular}{|l}
-- \\
\end{tabular} & -- & --- &.- & --- & -- \\
\hline \multirow{2}{*}{ ETV } & -- & $0.000^{* * * *}$ & & -- & --- & -- & -- & -- & -- & $-{ }_{--}$ & -.- & -- & --- & $\overline{--}$ \\
\hline & -- & $(0.000)$ & & 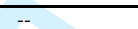 & -- & \begin{tabular}{|c|}
-- \\
-
\end{tabular} & -- & -- & \begin{tabular}{|l|}
-- \\
\end{tabular} & \begin{tabular}{|l|}
-- \\
\end{tabular} & .-- & -- & --- & -- \\
\hline \multirow{2}{*}{ WCI } & -- & -- & $0.013^{* * * *}$ & -- & \begin{tabular}{|ll}
-- & \\
\end{tabular} & \begin{tabular}{|l}
-- \\
\end{tabular} & -- & -- & \begin{tabular}{|ll}
-- & \\
\end{tabular} & \begin{tabular}{|l}
-- \\
\end{tabular} & 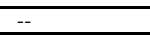 & -- & --- & -- \\
\hline & -- & -- & $\begin{array}{ll}(0.004) \\
\end{array}$ & -- & \begin{tabular}{|l|l}
-- & \\
\end{tabular} & $-{ }_{--}$ & -- & -- & \begin{tabular}{|c|c|}
-- & \\
\end{tabular} & -- & --- & -- & -- & -- \\
\hline \multirow{2}{*}{$D I S$} & -- & -- & -- & $0.047^{* * *}$ & -- & \begin{tabular}{|l|}
-- \\
\end{tabular} & -- & -- & \begin{tabular}{|l|}
-- \\
\end{tabular} & \begin{tabular}{|l|}
-- \\
\end{tabular} & -- & -- & --- & -- \\
\hline & - & -- & -- & $(0.013)$ & & \begin{tabular}{|l}
-- \\
\end{tabular} & -- & -- & -- & -- & --- & -- & --- & -- \\
\hline \multirow{2}{*}{ PROJ } & -- & -- & -- & -- & $0.009^{* *}$ & \begin{tabular}{|l|}
-- \\
\end{tabular} & -- & -- & \begin{tabular}{|l|}
-- \\
\end{tabular} & \begin{tabular}{|l|}
-- \\
\end{tabular} & 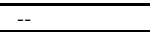 & -- & -- & -- \\
\hline & -- & -- & \begin{tabular}{|l}
-- \\
\end{tabular} & -- & \begin{tabular}{|l}
$(0.005)$ \\
\end{tabular} & -- & \begin{tabular}{|l|}
-- \\
\end{tabular} & -- & \begin{tabular}{|ll}
-- \\
\end{tabular} & -- &.-- & -- & -- & -- \\
\hline \multirow{2}{*}{$S U B$} & -- & -- & -- & -- & & $0.007^{*}$ & --- & -- & \begin{tabular}{|l|}
-- \\
\end{tabular} & \begin{tabular}{|l}
-- \\
\end{tabular} & --- & -- & --- & -- \\
\hline & -- & -- & -- & -- & & \begin{tabular}{|l|}
$(0.004)$ \\
\end{tabular} & -- & -- & \begin{tabular}{|l|}
-- \\
\end{tabular} & -- & -.- & -- & --- & -- \\
\hline \multicolumn{15}{|l|}{ Political incentives } \\
\hline \multirow{2}{*}{$L_{-} G O V$} & -- & -- & -- & -- & -- & \begin{tabular}{|l|}
-- \\
\end{tabular} & \begin{tabular}{|l|}
-0.001 \\
\end{tabular} & 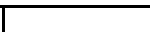 & \begin{tabular}{|l|}
-- \\
\end{tabular} & \begin{tabular}{|l}
-- \\
\end{tabular} & --- & -- & --- & -- \\
\hline & -- & -- & $\begin{array}{ll}-- \\
\end{array}$ & -- & -- & \begin{tabular}{|l|l|}
-- \\
\end{tabular} & \begin{tabular}{|l|}
$(0.010)$ \\
\end{tabular} & & \begin{tabular}{|l|}
-- \\
\end{tabular} & \begin{tabular}{|l|}
-- \\
\end{tabular} & $-\ldots$ & -- & --- & -- \\
\hline \multirow{2}{*}{ INST } & -- & -- & \begin{tabular}{|l|}
-- \\
\end{tabular} & -- & \begin{tabular}{|l|}
-- \\
\end{tabular} & \begin{tabular}{|l|}
-- \\
\end{tabular} & $-0.024^{* * * * *}$ & & \begin{tabular}{|l|}
-- \\
\end{tabular} & \begin{tabular}{|l|}
-- \\
\end{tabular} & -- & -- & -- & -- \\
\hline & -- & -- & -- & -- & --- & \begin{tabular}{|l|}
-- \\
\end{tabular} & \begin{tabular}{|l|l|}
$(0.008)$ \\
\end{tabular} & & \begin{tabular}{|l|l}
-- \\
\end{tabular} & \begin{tabular}{|l|}
-- \\
\end{tabular} & & -- & -- & -- \\
\hline \multirow{2}{*}{$P \_E N T$} & -- & -- & \begin{tabular}{|l}
-- \\
\end{tabular} & -- & \begin{tabular}{|l}
-- \\
\end{tabular} & \begin{tabular}{|l|}
-- \\
\end{tabular} & $-0.087^{* * * * *}$ & - & \begin{tabular}{|l|}
-- \\
\end{tabular} & \begin{tabular}{|l|}
-- \\
\end{tabular} & & -- & --- & -- \\
\hline & -- & -- & -- & 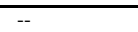 & -- & \begin{tabular}{|l|}
-- \\
\end{tabular} & $(0.011)$ & 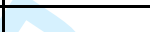 & \begin{tabular}{|l|}
-- \\
\end{tabular} & \begin{tabular}{|l|}
-- \\
\end{tabular} & -- & -- & -- & -- \\
\hline \multirow{2}{*}{ PRIV_COM } & -- & -- & \begin{tabular}{|l|}
-- \\
\end{tabular} & -.- & -.- & \begin{tabular}{|l|}
-- \\
\end{tabular} & $-0.024 * *$ & - & \begin{tabular}{|ll}
- \\
\end{tabular} & \begin{tabular}{|l|}
-- \\
\end{tabular} & .-- & -- & -- &.- \\
\hline & -- & -- & -- & -- & -- & \begin{tabular}{|l|}
-- \\
\end{tabular} & $(0.011)$ & & \begin{tabular}{|l|}
-- \\
\end{tabular} & \begin{tabular}{|l}
-- \\
\end{tabular} & -.- & -- & -- & -- \\
\hline \multicolumn{15}{|l|}{ Opportunistic behaviour } \\
\hline \multirow{2}{*}{ OPEN } & -- & -- & -- & -- & -- & \begin{tabular}{|c|}
-- \\
\end{tabular} & -- & $0.031^{* * * *}$ & 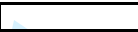 & \begin{tabular}{|l}
-- \\
\end{tabular} & -- & -- & -- & -- \\
\hline & -- & -- & \begin{tabular}{|l}
-- \\
\end{tabular} &.-- & -- & \begin{tabular}{|ll}
-- \\
\end{tabular} & -- & $\begin{array}{l}(0.005) \\
\end{array}$ & & \begin{tabular}{|ll}
-- \\
\end{tabular} & --- & -- & -- & - \\
\hline R WBID FTV & -- & -- & \begin{tabular}{|l}
-- \\
\end{tabular} & 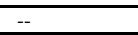 & \begin{tabular}{|ll}
-- \\
\end{tabular} & -- & -- & -- & -0.479 **** & & -.- & -- & --- & -- \\
\hline$R_{-}$WBID_ETV & -- & -- & -- & -- & -- & \begin{tabular}{|l|}
-- \\
-
\end{tabular} & -- & -- & \begin{tabular}{|l|l|}
$(0.020)$ \\
\end{tabular} & & -- & -- & --- & -- \\
\hline$P$ BID & -- & -- & \begin{tabular}{|l}
-- \\
\end{tabular} & -- & \begin{tabular}{|ll}
-- \\
\end{tabular} & \begin{tabular}{|l|l}
-- \\
\end{tabular} & --- & -- & & \begin{tabular}{|l|}
$0.000^{*}$ \\
\end{tabular} & & -- & -- & - \\
\hline$P \_B I D$ & -- & -- & -- &.-- & 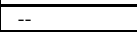 & -- & -- & -- & \begin{tabular}{|l|l}
-- & \\
\end{tabular} & \begin{tabular}{|l|}
$(0.000)$ \\
\end{tabular} & & -- & --- & -- \\
\hline LEAD & -- & -- & -- & --- & \begin{tabular}{|l|}
-- \\
\end{tabular} & \begin{tabular}{|l|l}
-- \\
\end{tabular} & & -- & \begin{tabular}{|l|l}
-- & \\
\end{tabular} & $-\omega_{-1}$ & $0.000^{*}$ & & & -- \\
\hline & -- & -- & -- & -- & \begin{tabular}{|l}
-- \\
\end{tabular} & \begin{tabular}{|l}
-- \\
\end{tabular} & & -- & \begin{tabular}{|l}
-- \\
\end{tabular} & \begin{tabular}{|l|}
-- \\
\end{tabular} & $(0.000)$ & & & -- \\
\hline & -- & -- & \begin{tabular}{|l}
-- \\
\end{tabular} & $-\ldots$ & \begin{tabular}{|ll}
-- \\
\end{tabular} & \begin{tabular}{|ll}
-- \\
\end{tabular} & & -- & \begin{tabular}{|l|l}
-- & \\
\end{tabular} & \begin{tabular}{|l|l|}
-- & \\
\end{tabular} & 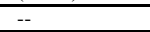 & $-0.001 * *$ & & $-\ldots$ \\
\hline$I N T$ & -- & -- & \begin{tabular}{|l}
-- \\
\end{tabular} & -- & \begin{tabular}{|l}
-- \\
\end{tabular} & \begin{tabular}{|ll}
-- & \\
\end{tabular} & --- & -- & \begin{tabular}{|ll}
-- \\
\end{tabular} & \begin{tabular}{|l|l}
-- \\
\end{tabular} & -- & $(0.001)$ & & -- \\
\hline Corruption & & & & & & & & & & & & & & \\
\hline GP INDEX & -- & -- & -- & -- & -- & \begin{tabular}{|l|}
-- \\
\end{tabular} & & -- & \begin{tabular}{|l|}
-- \\
\end{tabular} & \begin{tabular}{|l|}
-- \\
\end{tabular} & $-\ldots$ & -- & $0.022^{* * * *}$ & \\
\hline & & -- & \begin{tabular}{|l}
-- \\
\end{tabular} & & 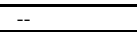 & -- & & - & --- & $-{ }_{--}$ & $=$ & & $(0.002)$ & \\
\hline Other covariates & & & & & & & & & & & & & & \\
\hline$E X_{-} T$ & -- & -- & \begin{tabular}{|l|l}
-- & \\
\end{tabular} & E & \begin{tabular}{|ll}
-- & \\
\end{tabular} & \begin{tabular}{|l|l}
-- \\
\end{tabular} & - & \begin{tabular}{|l|l}
-- \\
\end{tabular} & \begin{tabular}{|l|l}
-- \\
\end{tabular} & \begin{tabular}{|ll}
-- \\
\end{tabular} & \begin{tabular}{|ll}
-- \\
\end{tabular} & -- & -- & $0.003^{* * *}$ \\
\hline Controlling for vear of award & ves & ves & ves & ves & \begin{tabular}{|c|} 
ves \\
\end{tabular} & \begin{tabular}{|l|} 
ves \\
\end{tabular} & vee & \begin{tabular}{|l|}
-- \\
$Y e s$ \\
\end{tabular} & \begin{tabular}{|l|}
-- \\
ves \\
\end{tabular} & \begin{tabular}{|l|}
-- \\
ves \\
\end{tabular} & $\frac{--}{2 \text { ves }}$ & $\frac{--}{y e s}$ & $-x_{\text {- }}$ & $(0.001)$ \\
\hline Controlling for sector & yes & yes & \begin{tabular}{|l|} 
yes \\
\end{tabular} & yes & \begin{tabular}{|l|} 
yes \\
\end{tabular} & \begin{tabular}{|l|} 
yes \\
\end{tabular} & \begin{tabular}{|l|} 
yes \\
\end{tabular} & \begin{tabular}{|l|} 
Yes \\
Yes \\
\end{tabular} & \begin{tabular}{|l} 
yes \\
yes \\
\end{tabular} & \begin{tabular}{|l} 
yes \\
yes \\
\end{tabular} & \begin{tabular}{|l} 
yes \\
yes
\end{tabular} & $\begin{array}{ll}\text { yes } \\
\text { yes }\end{array}$ & \begin{tabular}{|l}
$y e s$ \\
yes
\end{tabular} & $\begin{array}{l}\text { Tes } \\
\text { Yes }\end{array}$ \\
\hline Observations & 9,888 & $\begin{array}{ll}y, 888 \\
\end{array}$ & \begin{tabular}{|l|}
$y, 8 s$ \\
9,888 \\
\end{tabular} & \begin{tabular}{|ll} 
yes & 9,888 \\
\end{tabular} & \begin{tabular}{|ll} 
yes & 9,888 \\
\end{tabular} & \begin{tabular}{|l|}
$y s, 888$ \\
\end{tabular} & \begin{tabular}{|ll}
$y e s$ & 9,888 \\
\end{tabular} & \begin{tabular}{|l|l|}
1 & 9,888 \\
\end{tabular} & \begin{tabular}{|l|}
$y, 888$ \\
\end{tabular} & 9,888 & 9,888 & 9,888 & 9,888 & 9,888 \\
\hline Uncensored & 7,571 & 7,571 & 7,571 & 7,571 & 7,571 & 7,571 & 7,571 & 7,571 & 7,571 & 7,571 & 7,571 & 7,571 & 7,571 & 7,571 \\
\hline Number of sector & 16 & 16 & 16 & 16 & 16 & 16 & 16 & 16 & 16 & 16 & 16 & 16 & $\begin{array}{r}16 \\
\end{array}$ & 16 \\
\hline Log likelihood & 869.8914 & 770.3344 & \begin{tabular}{|l|l|}
739.5762 \\
\end{tabular} & 741.5705 & 736.63889 & \begin{tabular}{|l|}
735.69725 \\
\end{tabular} & 781.0727 & 757.3792 & \begin{tabular}{|l|}
1022.4845 \\
\end{tabular} & \begin{tabular}{|l|}
737.2951 \\
\end{tabular} & 736.1421 & 737.1671 & 802.8068 & 741.9462 \\
\hline Wald & $x^{2}(5)=279.32 * * * *$ & $x^{2}(5)=77.05 * * *$ & $x^{2}(5)=15.35^{\text {****** }}$ & $x 2(5)=19.36 * * *$ & $x^{2}(5)=9.48^{*}$ & $x^{2}(5)=8.96^{*}$ & $x 2(8)=98.48 * * *$ & $x 2(5)=50.90^{* * * *}$ & \begin{tabular}{|l|l}
$x^{2}(25)=$ \\
$595.52^{* * * *}$
\end{tabular} & $x^{2}(5)=9.78^{*}$ & $x^{2}(5)=7.37^{*}$ & $x(2)=10.52^{*}$ & $x^{2}(5)=143.313^{* * * *}$ & $x 2(5)=20.12^{* * * *}$ \\
\hline
\end{tabular}

(1) Bootstrap standard errors in parentheses

* significant at 10\%; significant at $5 \%$; *** significant at $1 \%$

\# The coefficients of the variables representing the different governance structures are estimated with respect to C_GOV

Editorial Office, Dept of Economics, Warwick University, Coventry CV4 7AL, UK 
Table A.3 - Tobit estimation results for adaptation costs (excluding roads and highways )

\begin{tabular}{|c|c|c|}
\hline \multicolumn{3}{|c|}{$\begin{array}{l}\text { INDEPENDENT VARIABLE: } \boldsymbol{A C} \text { ( ADAPTATION COSTS ) } \\
\text { DATA SAMPLE: } 6,667 \text { OBSERVATIONS RELATIVE TO } 15 \text { SECTORS } \\
\text { EXCLUDING "ROADS AND HIGHWAYS" }\end{array}$} \\
\hline Explanatory variable & Tobit & Tobit random effects (1) \\
\hline \multirow{2}{*}{ CONSTANT } & $0.450^{* * * *}$ & $0.452 * * *$ \\
\hline & $(0.029)$ & $(0.031)$ \\
\hline \multicolumn{3}{|l|}{ Complexity of works } \\
\hline \multirow{2}{*}{$E D$} & $0.000^{* * * *}$ & $0.000^{* * * *}$ \\
\hline & $(0.000)$ & $(0.000)$ \\
\hline \multirow{2}{*}{ ETV } & 0.000 & 0.000 \\
\hline & $(0.000)$ & $(0.000)$ \\
\hline \multirow{2}{*}{$W C I$} & $0.013^{* * *}$ & $0.013^{* * * *}$ \\
\hline & $(0.003)$ & $(0.004)$ \\
\hline \multirow{2}{*}{ DIS } & $0.033^{* * *}$ & $0.033^{* * *}$ \\
\hline & $(0.013)$ & $(0.014)$ \\
\hline \multirow{2}{*}{ PROJ } & $0.012 * *$ & $0.013^{* *}$ \\
\hline & $(0.005)$ & $(0.006)$ \\
\hline \multirow{2}{*}{$S U B$} & 0.000 & 0.000 \\
\hline & $(0.005)$ & $(0.005)$ \\
\hline \multicolumn{3}{|l|}{ Political incentives } \\
\hline \multirow{2}{*}{$L_{-} G O V$} & $-0.021 * * *$ & $-0.017 * *$ \\
\hline & $(0.008)$ & $(0.009)$ \\
\hline \multirow{2}{*}{ INST } & -0.000 & 0.000 \\
\hline & $(0.009)$ & $(0.011)$ \\
\hline \multirow{2}{*}{ P_ENT } & $-0.085^{* * * *}$ & $-0.086^{* * * *}$ \\
\hline & $(0.014)$ & $(0.015)$ \\
\hline \multirow{2}{*}{ PRIV_COM } & $-0.041 * * *$ & $-0.035 * * *$ \\
\hline & $(0.012)$ & $(0.012)$ \\
\hline \multicolumn{3}{|l|}{ Opportunistic behaviour } \\
\hline \multirow{2}{*}{ OPEN } & -0.007 & -0.006 \\
\hline & $(0.006)$ & $\begin{array}{l}(0.006) \\
\end{array}$ \\
\hline \multirow{2}{*}{$R \_W B I D \_E T V$} & $-0.475^{* * * *}$ & $-0.477 * * *$ \\
\hline & $(0.028)$ & $(0.029)$ \\
\hline \multirow{2}{*}{$P \_B I D$} & $0.000^{*}$ & $0.000^{*}$ \\
\hline & $(0.000)$ & $(0.000)$ \\
\hline \multirow{2}{*}{$L E A D$} & $0.000^{* * *}$ & $0.000^{\text {*** }}$ \\
\hline & $(0.000)$ & $(0.000)$ \\
\hline \multirow{2}{*}{$I N T$} & -0.000 & -0.000 \\
\hline & $(0.001)$ & $(0.001)$ \\
\hline \multicolumn{3}{|l|}{ Corruption } \\
\hline GP INDEX & 0.001 & 0.001 \\
\hline$G P \_I N D E X$ & $(0.002)$ & $(0.002)$ \\
\hline Other covariates & & \\
\hline$T Y_{T}$ & $0.005 * * *$ & $0.005^{* * * *}$ \\
\hline$E X_{-} \boldsymbol{I}$ & $(0.001)$ & $(0.001)$ \\
\hline Controlling for year of a ward & yes & Yes \\
\hline Controlling for sector & pooling & Yes \\
\hline Observations & 6,667 & 6,667 \\
\hline Uncensored & 5,249 & 5,249 \\
\hline Number of sector & 15 & 15 \\
\hline Rho & -- & 0.01035 \\
\hline Pseudo $R^{2}$ & 0.4867 & -- \\
\hline Log likelihood & 946.9754 & 939.57 \\
\hline$L R \chi^{2}$ & $\chi 2(21)=620.00 * * *$ & -- \\
\hline Wald & -- & $586.74^{* * * *}$ \\
\hline (2) LR test ( $p$-value) & -- & 0.0000 \\
\hline
\end{tabular}

Notes: (1) Bootstrap standard errors are reported in parentheses. (2) The LR test is used to compare the Tobit and random-effects Tobit models. Robust standard errors are reported in parentheses

$* * *, * *$ and $*$ denote significance at 1,5 and 10 per cent levels, respectively. 


\section{Table A.4 - Tobit estimation results for adaptation costs (roads and highways only)}

\begin{tabular}{|c|c|}
\hline \multicolumn{2}{|c|}{$\begin{array}{l}\text { INDEPENDENT VARIABLE: } \boldsymbol{A C} \text { ( ADAPTATION COSTS ) } \\
\text { DATA SAMPLE: } 3,221 \text { OBSERVATIONS RELATIVE TO "ROADS } \\
\text { AND HIGHWAYS" ONLY }\end{array}$} \\
\hline Explanatory variable & Tobit \\
\hline \multirow{2}{*}{ CONSTANT } & $0.483^{* * * *}$ \\
\hline & $(0.056)$ \\
\hline \multicolumn{2}{|l|}{ Complexity of works } \\
\hline \multirow{2}{*}{$E D$} & $0.000^{* * * *}$ \\
\hline & $(0.000)$ \\
\hline \multirow{2}{*}{ ETV } & -0.000 \\
\hline & $(0.000)$ \\
\hline \multirow{2}{*}{$W C I$} & $0.027^{* * * *}$ \\
\hline & $(0.008)$ \\
\hline \multirow{2}{*}{$D I S$} & 0.023 \\
\hline & $(0.022)$ \\
\hline \multirow{2}{*}{ PROJ } & 0.011 \\
\hline & $(0.008)$ \\
\hline \multirow{2}{*}{$S U B$} & 0.010 \\
\hline & $(0.007)$ \\
\hline \multicolumn{2}{|l|}{ Political incentives } \\
\hline \multirow{2}{*}{$L_{-} G O V$} & -0.062 \\
\hline & $(0.041)$ \\
\hline \multirow{2}{*}{ INST } & -0.036 \\
\hline & $(0.046)$ \\
\hline \multirow{2}{*}{ P_ENT } & $-0.134 * * *$ \\
\hline & $(0.042)$ \\
\hline \multirow{2}{*}{ PRIV_COM } & -0.046 \\
\hline & $(0.042)$ \\
\hline \multicolumn{2}{|l|}{ Opportunistic behaviour } \\
\hline \multirow{2}{*}{ OPEN } & $0.019^{* * *}$ \\
\hline & $(0.009)$ \\
\hline \multirow{2}{*}{$R_{-} W B I D \_E T V$} & $-0.525^{* * * *}$ \\
\hline & $(0.037)$ \\
\hline \multirow{2}{*}{$P \_B I D$} & 0.000 \\
\hline & $(0.000)$ \\
\hline \multirow{2}{*}{$L E A D$} & 0.000 \\
\hline & $(0.000)$ \\
\hline \multirow{2}{*}{ INT } & 0.001 \\
\hline & $(0.001)$ \\
\hline \multicolumn{2}{|l|}{ Corruption } \\
\hline \multirow{2}{*}{ GP_INDEX } & $0.011^{* * * *}$ \\
\hline & $(0.004)$ \\
\hline \multicolumn{2}{|l|}{ Other covariates } \\
\hline$E X T$ & $0.012 * * *$ \\
\hline$E X_{-} T$ & $(0.002)$ \\
\hline Controlling for year of a ward & Yes \\
\hline Sector & Only Roads and highways \\
\hline Observations & 3,221 \\
\hline Uncensored & 2,322 \\
\hline Number of sector & 1 \\
\hline Pseudo $R^{2}$ & 0.1896 \\
\hline$L R \gamma^{2}$ & $\chi^{2}(21)=448.25^{* * * *}$ \\
\hline Log likelihood & 304.7079 \\
\hline
\end{tabular}

Robust standard errors are reported in parentheses

$* * *, * *$ and $*$ denote significance at 1,5 and 10 per cent levels, respectively. 